\title{
"Into the Realm of the Politically Incorrect": Intercultural Encounters in a Service-Learning Program
}

\author{
Christelle Palpacuer-Lee \\ Rutgers University \\ U.S.A. \\ Jessie Hutchison Curtis \\ Rutgers University \\ U.S.A.
}

\begin{abstract}
Now more than ever, teachers of world languages are encouraged to become intercultural mediators in their communities and classrooms. This study describes the impact of an innovative community-based teacher education program for developing participants' interculturality. Building on narrative methods of investigation, we explore the potential of communitybased service-learning as a social space in which participants learn to recognize and mediate worldviews. The data come primarily from field observations and pre-service teachers' journaled reflections. We illustrate our findings through a series of narratives that serve as a frame for locating cultural recognition and learning.
\end{abstract}

KEYWORDS: service-learning, identity, interculturality, critical pedagogy, intercultural citizenship

\author{
Conceptual Framework \\ The Study \\ Data and Analysis \\ Findings \\ Openings and Implications \\ Notes \\ References \\ Author Contact
}

In the United States, everyday experiences of bilingualism ${ }^{1}$ and heterogeneity exist in tension with the monolingual imaginary of the nation, operationalized through a de facto English-only policy in education (Mencken, 2008) and a narrow citizenship identity attached to English (Bale, 2011). At the global level, various tensions push toward the normalization of monolingual national identities (Blommaert \& Backus, 2013; Ramanathan, 2013). These tensions are often reflected in classrooms. Although U.S. communities and schools are rapidly diversifying, the population of U.S. pre-service teachers remains largely White, female, and middle-class, a trend that is frequently documented in the research literature (Feistritzer, 2011; Haddix, 2015). Educators agree that pre- 
service teachers need to be equipped with direct and scaffolded experiences of diversity in order to be effective. Ladson-Billings (2006) captures this imperative, "It's not the culture of poverty, it's the poverty of culture," in her call to include offcampus, community experiences in teacher preparation overall.

The capacity to mediate intercultural (with others) and intracultural (with self) encounters in diverse classrooms has recently become an imperative in teacher education worldwide. This article specifically focuses on the preparation of foreign language teachers in the United States. The American Association of Teachers of Foreign Languages (ACTFL) emphasizes the need for global competence in foreign language education in its 2014 position statement. This document, echoing the U.S. Department of Education's 2012 international agenda for global citizenship ${ }^{2}$, states that global competence is "demonstrated by investigating the world, recognizing and weighing perspectives, acquiring and applying disciplinary and interdisciplinary knowledge, communicating ideas, and taking action" (ACTFL, 2014). Teachers need to prepare intercultural and global citizens and must first themselves develop intercultural awareness and competence. However, there are few concrete models for how intercultural mediation skills and dispositions can be developed in foreign language teacher education programs (Scarino, 2014).

This paper addresses this gap in three ways: first, we critically examine how a community-based service-learning program can afford opportunities for discursively negotiating encounters with alterity; second, we foreground the experiences and voices of pre-service world language teachers through their retellings of such encounters; and third, we suggest ways to address intercultural competence through engagement with local and global communities in world language teacher preparation programs.

\section{Conceptual Framework}

Intercultural competence is undoubtedly viewed as a necessary quality for both language learners and teachers (Byram, 1997). Several scholars have laid the groundwork to define, theorize and operationalize interculturality and intercultural competence in applied linguistics and teacher education (Byram, 2008 Kramsch, 1998, 2014; LoBianco, 2014). Overall, intercultural competence, sometimes referred to as global competence in educational policy documents, is a multidimensional construct that references the symbolic capacity to mediate between cultures, to seek ways "to understand the Other on the other side of the border" (Kramsch, 1998, p. 81). However, intercultural competence "is not something one either has or not" (Hua, 2014, p. 157). Adopting an ecological perspective that shifts away from the notion of competence, Avineri (2015) highlights the complex enterprise of intercultural dialogue as the negotiation of several layers of discourse that she labels "nested interculturalities." Participants in intercultural dialogue negotiate ideologies, agendas, and subjectivities all embedded in space, time, and narratives and embodied by others and themselves 
(Avineri, 2015). Navigating this complexity is hard work from which conflict, resistance, and disruptions are likely to arise (Smolcic \& Katunich, 2017). In this view, interculturality is also a form of action: a reflective, critical, and ethical "oppositional practice" (Kramsch \& Nolden, 1994). Within this framework, educators who seek to support the negotiation of such complexity in interaction face methodological, programmatic, and practical challenges. First, since interculturality is emergent, shaped by socio-historical contexts, and involves a symbolic dimension, its emergence is difficult to isolate, capture, and assess (Kramsch \& Whiteside, 2008). Second, educators in the United States have focused on an agenda for praxis that is centered on the design of learning environments that are conducive to developing their students' dispositions and awareness towards alterity (Kearney, 2015; Kramsch, 1998), yet environments alone cannot be relied upon to produce intercultural dialogue that leads to learning (Byram, 2008). Third, language educators are currently trying to find ways to articulate, include, and support the negotiation of conflict (Phipps \& Levine, 2012) and to operationalize an intercultural pedagogy as "oppositional practice" (Avineri, 2015; Kramsch \& Nolden, 1994). In their attempts at preparing globally competent language teachers, language educators face the additional difficulty of providing space and time for interculturality in their curricula and training sequences (Byrd, Hlas, Watzke, \& Montes Valencia, 2011). When a whole class cannot be dedicated to interculturality, the teaching methods classes seem to offer an ideal forum for reflection and a path towards intercultural awareness (Sadler, 2014), but online classes (Belz, 2003; Leh, Grau, \& Guiseppe, 2015), study abroad (Kinginger, 2013), and even museums (Palpacuer, 2010) offer such spaces as well. Community-based service-learning programs have recently received attention from scholars whose social justice agendas converge with those of interculturalists on the very same issues of equity and citizenship (Gorski, 2008; Porto \& Byram, 2015). Despite this clustering of interests, the potential of community-based service-learning for fostering interculturality has not yet been fully explored (Smolcic \& Katurnich, 2017).

In recent years, community-based service-learning has become an opportunity for language educators to connect pre-service teachers with increasingly diverse schools and communities (Wurr, 2013). Such programs generally provide contexts to facilitate teachers' engagement with linguistically and culturally diverse students and to encourage educators to think of themselves as (inter)cultural beings and become aware of their social positioning in local and global communities (Angelova, 2001; Dooly, 2011; Hutchinson, 2011). These contexts, in which the community and the classroom are one and the same, provide a clinical setting in which pre-service teachers can potentially develop nuanced understandings of their own and of other cultures. Yet, issues arise: community-based programs bring power, privilege, and inequities to the fore. A number of educators operating from a critical perspective on service-learning have found that the power relations inherent in the structure of community-based service-learning, which frequently involves partnerships between well-resourced universities and marginalized communities, may reinforce discourses of community deficit and stereotyping (Boyle-Baise \& Kilbane, 2000; De Leon, 2014; 
Flower, 2002; Haddix, 2015; Kozma, 2015). In addition, contact between speakers of various cultures does not necessarily result in intercultural dialogue. This is a lesson learned from research on language and culture learning in immersive settings, such as study abroad contexts (Smolcic \& Katunich, 2017) and second language onsite or online classrooms (Martín-Rojo, 2013; Ware \& Kramsch, 2005). These findings are echoed by studies on the development of pre-service teachers' interculturality in service-learning programs at home (Angelova, 2001), abroad (Malewski, Sharma, \& Phillion, 2012; Palmer \& Menard-Warwick, 2012), or online (Porto, 2015). In such immersive environments, interculturality is negotiated and performed in non-linear ways, and participants grapple with power relations, identity, and discourses of membership. These concerns for power, equity, and reciprocity have led educators who employ critical service-learning to attend to program design that encourages sustained engagement, collaboration, and reflection (Curtis \& Curran, 2015). Sharing these concerns for equity, applied linguists increasingly recognize the need to examine how communities interact, in programs that rely on interactions as part of their curriculum (Overfield, 2007; Perren \& Wurr, 2015).

This paper contributes to this agenda by critically examining the emergence of interculturality in a community-based program and investigating the lived experiences of a group of pre-service language teachers as they navigate complex intercultural encounters. Here, we consider a community-based service-learning program focusing on a privileged world language, English.

\section{The Study}

The present exploratory qualitative study focuses on the experiences of a small group of pre-service teachers enrolled in a world language teacher preparation course that employs a service-learning model. The study is concerned with the ways pre-service language teachers navigate and negotiate complex intercultural encounters in community-based learning environments, and how these negotiations can inform their engagement with interculturality as "oppositional practice" (Kramsch \& Nolden, 1994). To do so, we designed a qualitative study that seeks to answer the following research questions:

1. In what ways, if any, do pre-service teachers negotiate interculturality through a community-based experience?

2. In what ways, if any, can these negotiations lead to change?

In this section, we first present an extensive description of the community and service-learning contexts for this study. These descriptions outline the critical orientation of the community-based program and its intentional disruptive stance. Then, we turn to the procedures of data collection and analysis, followed by a presentation of the findings. We conclude the article with a series of implications for practice and program design. 


\section{Community Context}

The service-learning program that represents the large context for this study takes place in the Riverside School District (a pseudonym), on the grounds of an elementary school. Globalization of economies and workforces has had an impact on the district. Riverside comprises long-standing African-American and Eastern European communities and newer Latino and Asian populations. The U.S. Census Bureau (2014) reports that family languages include English, Chinese, Spanish, Hebrew, Hindi, and Russian. In our work in Riverside, we have encountered Arabic-speaking families as well.

This diversity is mirrored in the schools. In 2010, the school district found that many parents were seeking instruction in English in order to be more involved in community and school life. In response, a partnership was formed with the local university's graduate school of education to provide support, in the form of English conversation practice. Pre-service foreign language teachers, who are fluent in English, would have the opportunity to interact with diverse families, and parents would be able to practice English at the nearby elementary school. This nascent partnership, called English Conversation for Parents and later conceptualized as Conversation Café, now comprises the service-learning component of core courses for pre-service world language teachers.

\section{Service-Learning Context}

While recognizing the material and practical necessity to learn English, the Conversation Café model employs the principles of community of practice (Wenger, 1998), an approach that values community funds of knowledge (Moll, Amanti, Neff, \& González, 1992) and encourages multi-directional flows of learning. In its implementation, this approach means that pre-service teachers and community members will engage in informal conversation but that the pre-service teachers will be responsible for the engagement of all participants with language, culture, and other community members. For example, pre-service teachers, as fluent English speakers, take responsibility for self-monitoring their amount and pace of talk, clarifying meaning, and inviting community members to contribute to conversation. Secondly, they encourage collaboration among community members, which means that family languages and emerging knowledge of English can be engaged. Thirdly, utilizing a community of practice approach means that pre-service teachers are asked to reflect on the contributions of community members to each conversation and to what they, the pre-service teachers, learn about culture and communication. Finally, as members of the Conversation Café community of practice, the pre-service teachers are prepared to take responsibility for the communicative burden that is usually imposed on the less fluent speaker in asymmetrical intercultural encounters (Bremer, Roberts, Vasseur, Simonot, \& 
Broeder, 1996; Dooley, 2009; Norton, 2013). From a professional development standpoint, the pre-service teachers learn specific skills and strategies to facilitate and engage in intercultural dialogue.

Ultimately, this service-learning program model is intentional about disrupting structural asymmetries embedded in language learning and teaching, by creating space for multi-directional learning. Even as the terms globalization and intercultural competence too frequently direct our gaze toward those cultures "out there," we acknowledge the historically rich linguistic and cultural diversity of U.S. citizenry "right here" in our practice (Darling-Hammond, 2009; Gándara \& Hopkins, 2010; Ladson-Billings, 2006). We, as educators, are concerned with promoting the educational equity so long overdue in the United States. The service-learning program and course not only work to socialize dominant-language speakers to taking responsibility for negotiating understanding in conversations with less fluent speakers, but also aim to provide pre-service teachers with a model for equity in their future classroom practice.

In the language teacher education program at our institution, pre-service language teachers enroll in a core content course on second language acquisition and participate in its embedded service-learning component, the Conversation Café, for eight consecutive weeks. The remaining seven weeks in the semester are dedicated to the discussion of theoretical issues pertaining to language learning and teaching, to the preparation for conversation sessions, and to reflective practice. Table 1 outlines the course structure.

Table 1. Structure of Core Course with Embedded Service Learning

\begin{tabular}{|c|c|c|}
\hline Location & Duration & Course Content \\
\hline On Campus & 3 weeks & $\begin{array}{l}\text { Reading } \\
\text { Discussions } \\
\text { Student Presentations } \\
\text { Lesson Preparation } \\
\text { Case Study Analysis }\end{array}$ \\
\hline $\begin{array}{l}\text { Off-campus } \\
\text { at Local } \\
\text { School } \\
\text { District }\end{array}$ & 8 weeks & $\begin{array}{l}30 \text { minutes of preparation } \\
60 \text { minutes of Conversation Café with community } \\
\text { members } \\
45 \text { minutes debrief and discussion }\end{array}$ \\
\hline On Campus & 4 weeks & $\begin{array}{l}\text { Case Study Analysis } \\
\text { Debriefs } \\
\text { Reflection }\end{array}$ \\
\hline
\end{tabular}

The course is a survey of the issues and principles related to second language and culture acquisition. Issues of language and identity, language and power, interaction, motivation and investment, mediation, and collaborative dialogue are 
contrasted and discussed in light of various theoretical approaches to languageand-culture learning and of personal experiences during the Conversation Café. After each meeting with their conversation partners from the community, the students are required to write a personal reflection journal in which they connect their readings and class discussion with their experiences.

\section{Participants}

Participants are pre-service teachers enrolled in a graduate teacher preparation course at a large, public university. Although everyone is invited to participate in the study, it is not a course requirement, and consent must be obtained in writing, through an IRB-approved form, in order to participate. IRB approval was received before the start of the course ${ }^{3}$. The authors are the instructors for this and other community-based courses in the teacher education program. Fourteen students enrolled in this class in order to fulfill a core requirement in their language teacher education program. Seven of the participants sought dual certification in English as a Second Language (ESL) and a World Language, while six pursued ESL certification, and one student focused on Foreign Language only.

In terms of the individual profiles of the 14 students enrolled, two were male and 12 were female, all between 21 and 28 years of age. There were no international students in this cohort. All the participants were fluent speakers of English and of at least an additional world language at various levels of proficiency. These additional languages included Spanish, Italian, Mandarin Chinese, German, Urdu, and Persian. Four students were bilingual, having grown up in bilingual Spanish and Chinese families. Data were collected over the course of the semester. The data included researcher observations and field notes, students' journal reflections and assignments, and mid-term and final course evaluations.

\section{Data and Analysis}

The reflective journals written by the pre-service teachers constitute the bulk of the data for this study and were triangulated with the researcher's field notes. Engaged in a cycle of action research, we began analyzing our data as the community-based program unfolded. During the semester, discussions were held during the core content class to re-focus and share interpretations of what had occurred. This collaborative process with the pre-service teachers allowed for an additional space for reflection and co-construction of meaning. Upon the completion of the course, we revisited the data, adopting a narrative approach. Our narrative analysis focused on the pre-service teachers' retellings of events that occurred spontaneously in the Conversation Café. We applied the "dimensions of narrative" framework developed by DeFina and Georgakopoulou (2012) to identify 
"tellable" events that presented a "breach" or a disruption of the pre-service teachers' expected norms. As a result, we identified focal stories of disruption that included conversations and events and that captured a disruption of the participants' norms, worldviews, and expectations, thus demanding to be unpacked. A second cycle of thematic analysis aimed at identifying motifs in each and across the focal stories. Identity negotiation emerged as a major theme among the pre-service teachers' narratives. Thus, we added another cycle of narrative analysis, this time to investigate interactional work (DeFina \& Georgakopoulou, 2012). Narrative is understood to be a resource that people draw upon in constructing their social identities (Bakhtin, 1935/1981; Barkhuizen, 2016). In this last phase of analysis, we adopted the narrative view that these identities unfold interactionally, representationally, and autobiographically, through language. To further understand the dissonances in the narratives we had selected, we employed positioning as an analytic tool to capture the moments when certain identities, or positions, became salient in our data (Davies \& Harré, 1990; Wortham, 2001).

\section{Findings}

The findings highlight the ways in which conversation, unpredictable by nature and intentionally organized in this program to disrupt asymmetries in linguistic resources, is a space where pre-service teachers potentially learn to negotiate differences in meaning and to re-negotiate their social identities. Employing positioning, we find that native speaker, teacher, and cultural expert are among the normalized social identities that became salient in these conversations. In this section we examine excerpts from three focal narratives, selected for their representativeness of the overall data.

\section{"How Can a Child Say This?"}

On Thursday nights, the library at Riverside Elementary School is busy and noisy. On these nights, pre-service teachers from the graduate school of education (GSE) meet with parents from the school district for an hour of English conversation. The pre-service teachers are prepared with activities and topics for these sessions. However, an important feature of what we call the Conversation Café is unscripted conversation. As community members settle into small groups, they update each other on work and family, celebrations, and visits, sharing their weekly news in English.

One night, $\mathrm{Fen}^{4}$ from China, joins a group that includes two American preservice teachers and three parents also from China. It is evident that Fen has a question for her American partners. She tells them: "On way back to school, my son said he is going to hell because he is not Christian." Looking around the table, Fen adds, "How can a child say this?" This question is followed by an 
uncomfortable silence. Bao, another participant at the table, mentions the practice of swearing on the Bible in court. One of the American pre-service teachers, Claire, attempts (and struggles with) an historical explanation. She says: "When the courts were founded, everyone was Christian so it was important and literal. Now it is a symbol. It is not so much religious. It is a symbol of saying the truth."

In response, Fen pulls a dollar bill out of her pocket, points at the text, and exclaims: "In God we trust!" The two pre-service teachers are taken by surprise, and Claire stumbles again as she attempts another explanation. The community members, however, have made a discovery and are not ready to abandon their quest for clues that connect religion to money and to their experiences of living in the United States. The conversation takes a different turn, and community members begin talking together in Mandarin, silencing their American partners. After a few minutes, the pre-service teachers reclaim the attention of the group and move on to a prepared activity, abandoning Fen's question and the group's inquiry altogether.

The group's brief but intense engagement with American cultural products, practices, and perspectives faded into silence. The issue raised by Fen was not resolved that day but made an impression on the pre-service teachers, as we learned from their reflective journals. Yvonne, the second pre-service teacher who formed part of the group, spontaneously revisits this conversation in her journal. She writes:

She [the parent from China] asked if Christianity was the only religion in America and if everyone believed in the Christian god. She told us that her son asked her in the car if she believed in God and that if she didn't she wouldn't be able to go to heaven. The woman looked honestly distressed by this and seemed to be looking for some sort of confirmation from us. What we were able to tell her was that the United States is full of many different religions and that most people are open to people who believe in different gods. I couldn't help but wonder where her son heard something like that (Yvonne, Reflection 2, October 10, 2014).

Yvonne further reports that Fen considered converting to Christianity: "She questioned whether her religious status was wrong and asked if she should convert if she wanted to learn English and stay in the country." Fen made visible a link between language, culture, and citizenship that the American pre-service teachers had not seen themselves. Yvonne's "I couldn't help but wonder" is the first step toward dismantling an invisible habitus. This revelation is confirmed by Claire in her journal (Claire, Reflection 2, October 10, 2014):

[S] he [the parent] began finding relevant pieces of religious influence floating all around her life and she began to question it. Does she need to be Christian to live in America? Are all Americans Christians?... The country seems to have more ties to Christianity than it does to diversity, so it's no wonder she was confused.

Fen is persistent in presenting evidence of her discovery. Claire writes, "She pointed out how on all the money it says 'In God We Trust' and how the students 
have to say the pledge of allegiance at school in the morning where they say 'One nation, under God."' Claire continues:

Honestly, this was incredibly astute of her to notice and I made the best effort that I could to explain to her why these things exist. I talked about how the founding fathers of the country were Christians, so many of their influences still linger, but not because the entire nation is Christian, but because it's more of a tradition and done to honor the founding fathers and the founding of the country. (Reflection 7, December 20, 2014)

In this reflection, Claire is able to acknowledge the disruptions that prompted Fen's question. Yet Claire runs into a wall - she is eager to contribute understanding, but can only offer reassurance. The analysis reveals that the pre-service teachers recognized how Fen's questions disrupt their norms, as well as their identities as teachers and cultural experts who are able to explain why things are the way they are. This is illustrated by Claire's comment, as she writes that "this was incredibly astute of her to notice" (Claire, Reflection 7, December 20, 2014). This observation constitutes a first step towards intercultural dialogue and provides us, as teacher educators, with a direction to support the participants' negotiations of difference in the service-learning program. We view this story as an interrupted intercultural encounter and as a catalyst that prompted us to investigate more deeply what happens in the Conversation Café. In subsequent analyses, we pulled additional stories like this one from our data. Next, we present two such narratives and zoom in on another conversation that took place in the local elementary school library.

\section{"Ok, So You Are the Teacher?"}

This time, around the table, there are two pre-service teachers and two community members. The English-speaking pre-service teachers are Daria and Yasmin. They are working with Svetlana from Poland and Silvia from China. Daria reports on the conversation in her journal.

We had been going around the table, introducing ourselves and getting to know one another. I mentioned that I was born and raised in the U.S. and Yasmin did the same, just briefly mentioning that her parents were from India ... Svetlana [a community member] looked at me and said, "Ok, so you are the teacher." This kind of struck me in an odd way, and I immediately said, "Yasmin and I are both the teachers. We're both here to be your conversation partners." I felt so awkward for a minute because it seemed like I was being perceived as the only expert English speaker at the table, completely excluding Yasmin. Perhaps this was because, to Svetlana, I somehow fit the stereotype of a native speaker ... (Daria, Reflection 2, September 24, 2014).

Daria, who is of European ancestry, reluctantly acknowledges that her ethnicity leads Svetlana to ascribe her with identities - native speaker of English, teacher, and expert - that exclude Yasmin. In Daria's re-telling, epistemic modalizations 
such as kind of, it seemed like, perhaps, and maybe index her uncertainty. As she says, her position is awkward. Daria is becoming aware of the identities she is being ascribed. She is also sensitive to the complex workings of identity and positioning as they apply to her peers. In her group, Yasmin can claim a professional identity as a teacher, but this claim may not be ratified. Instead, Yasmin is ascribed the identity of an English learner. Yet Yasmin is voiceless in this narration.

This conversation, and its interpretation by Daria, illustrates the persistence of the native / non-native speaker dichotomy, an ideology that critical applied linguists have long sought to dismantle (see Auerbach, 1993; Levine, 2013; Pennycook, 2007, for historical and political analysis and continued relevance to language teaching). Ethnographic and narrative studies have articulated the native / non-native speaker dichotomy as a power locus that implicates immigration status and ethnicity (for example, Bremer et al., 1996; Norton, 2013). This is illustrated in the short conversation between Svetlana and Daria. In addition, Daria's autobiographical account foregrounds one pre-service teacher's experience of how language operates as a locus of power in social interactions. This encounter can also afford Daria with new vocabulary to analyze her own relationships to language, and her positioning through language use. In the next excerpt, we finally hear from Yasmin, this time about her experience on the periphery of a different conversation.

\section{"Into the Realm of the Politically Incorrect"}

Yasmin reports on the last Conversation Café in which she participated. At her table, she interacts with Sally and Moira, two friends who are both speakers of Arabic. The two women are homemakers in their thirties. Moira has been coming to the Conversation Café for several years while Sally is a more proficient newcomer accompanying her friend that evening. Hank is also sitting at their table. Hank is in his late thirties and a speaker of Mandarin. In her journal, Yasmin writes:

On the last day ... another woman [Sally] who was Muslim accompanied Moira. ... The conversation took an interesting turn when Hank ... began asking Sally questions about the dress of Muslim women. So used to being an ambassador of American culture, I enjoyed seeing another culture have its moment to shine. By eliciting information about the adults' home countries and festivals, we had tried to show that we valued their culture just like they valued ours. However, by sticking to neutral parts of culture such as food and festivals, we had perhaps denied them the ability to express the parts of their culture that contradicted with American culture. We ourselves could have grown more if we had been open to conversations that would challenge our own cultural beliefs.... The conversation that encompassed deeper issues of culture took place almost while we watched with baited [sic] breath, hoping that it would not go "too far" into the realm 
of the politically incorrect. Well, perhaps we need to let that breath go and allow ourselves to go far. (Yasmin, Reflection 7, December 18, 2014).

Yasmin says she is "used to being an ambassador of American culture," and taking an evaluative role but here positions herself as a spectator, enjoying and watching the conversation from the sidelines. Yasmin hesitates at taking a political approach while the community members go right into it. She is on the cusp, indexed by the statement, "Perhaps we need to let that breath go and allow ourselves to go far." This is such a wonderful observation. What does it mean to "go far"? Where would this risky stance take the group?

The notion of "politically correct" suggests another way that language is the main character in this conversation, as a shaper of discourse (Wortham, 2004). What linguistic tools can we, teacher educators, provide for the pre-service teachers to engage in controversial conversations while adopting an intercultural stance? Our role in this service-learning program is to offer a platform where these concerns can be voiced, and practices can be negotiated and co-constructed. In addition, considering that it includes reflection and engagement with language, we found that the research process itself can provide an additional space for the preservice teachers to grapple with the issues, questions, and silences that make up the interactions in the Conversation Café (Rampton \& Charalambous, 2016).

\section{Conclusions}

We began this research project with the goal of identifying how pre-service language teachers navigate and negotiate complex intercultural encounters in community-based learning environments and how these negotiations can inform their engagement with interculturality as "oppositional practice" (Kramsch \& Nolden, 1994). The three narratives we shared in this paper foreground the unexpected, the unpredictable, and the uncomfortable in intercultural conversations. They highlight how interculturality in community-based servicelearning programs is not a quiet, peaceful, middle ground. It is instead complex, controversial, and political, and it is not always successful (Dervin \& Machart, 2015). The three narratives described how navigating such complex encounters involves a critical stance towards the known and the expected, a destabilizing process that can lead to attitudes of empathy and humility. Engaging with interculturality can also result in action. Beyond communication and competence, interculturality invites reflective, critical, and ethical practices.

Change was the focus of our second research question. We wondered how experiences of interculturality in community-based learning could lead to change. The data illustrate how pre-service teachers displayed self-awareness of their interculturality, as they recognized their multiple social positionings and their privileges as educated speakers of a dominant language. Noticeable in the excerpts are the silences, important moments when the pre-service teachers find themselves toppled from the center to the margins of conversations (such as when 
the parents begin to speak together in Mandarin or when Yasmin "watches" with bated breath). In this program, even if interculturality is not the explicit focus of the community experience, the pre-service teachers grapple with identity, positioning, and conflicting discourses about themselves and others. Out of these struggles and dissonances came not only self-awareness but also empathy, humility, and change. We, as educators, need to foreground such transformative experiences. Grappling with controversy represents an opportunity to destabilize the traditional discourse of U.S. pre-service teachers who are participating in community-based learning from their relative position of privilege, to "help others" learn English. These silences are opportunities for inquiry and learning.

\section{Openings and Implications}

Going back to Fen's plea, "How can a child say this?" we hear this question as a call to equip pre-service language teachers with the discursive tools to explore and pursue the worldviews of others and their own. Community settings offer preservice teachers spaces where they learn to navigate and negotiate their identities as members of a diverse academic community, as members of ancestral groups, as Americans, as gendered beings, and as speakers of English. At the same time, they offer resources for class discussions, and instruct us, who are so closely involved as teacher-researchers. The pre-service teachers cited here rejected the stereotypes voiced by community members. Yet with additional discursive tools to pursue this line of inquiry, these educators would be pushed to recognize and explore the legacy of broader discourses and social categories and could be emboldened "to let that breath go and allow [themselves] to go far." In practice, this would entail the disruption of the relative (and unacknowledged) security and privilege that originates from membership in the group of dominant language speakers, the university, and the power that flows toward the teacher in a traditional classroom. In community-based learning, pre-service teachers find that their assumptions are challenged and identities must be renegotiated.

Our role as teacher educators in this service-learning program is to offer a platform where these concerns can be voiced, and practices re-negotiated and coconstructed in dialogue. The findings highlight the challenges of how to teach interculturality. Perhaps, as Dervin and Machart (2015) suggest, culture should be kept out of the equation and replaced by a critical post-intercultural stance that closely examines identity construction and marginalization in interaction. In fact, this is the direction suggested by Rampton and Charalambous (2016) as well. As we attempt to do so, we recycle our findings into practice, bringing to the fore the unscripted, the margins, the in-between, the uncomfortable, the unsaid, and the interstices. This, we believe, is the research agenda and opportunity offered by community-based learning for second and foreign language learning.

What do these findings suggest for our program? First, we can use narratives like Daria's to break the silence about social positioning in language teaching practice (Rampton \& Charalambous, 2016). Second, we can use Daria's 
and Yasmin's accounts to bring awareness of language as indexical of positionings and identities in social categories that teachers may need to negotiate in interactions with their future students. We can also use Claire's and Yvonne's accounts as documents in the program to redirect our participants' attention to the centrality of language in the development of an intercultural stance for language teaching (Levine, 2013; Scarino, 2014; Ware, 2016). And finally, we can continue to carve spaces, including reflection and debrief sessions with individuals and small groups, for these processes to be voiced and unpacked. To this end, we have decided to pilot individual interviews with pre-service teachers as instructional and research strategies. As Rampton and Charamboulos (2016) suggest, we may also find that the interview itself, as part of the research process, provides an additional space for teacher reflection on the interactions and silences that take place in the Conversation Cafés. For instance, Claire and the researchers piloted the post-program interview to negotiate additional meanings related to the experiences afforded by the Conversation Café. An interesting outcome to this interaction was to hear Claire refine her understanding of culture and voice her recognition of the historical and social locations of herself and others. She commented:

[Culture is] part of everyday life not that your blinders are up but it's kind of just integrated and so unless it's in sort of direct contact with you I don't think you're going to pay attention to it / it's like when you're in your house and you have this furniture and it's always there and you put your keys on the table and then one day you go and you throw your keys where the table is and the table is not there anymore and the keys fall on the floor. (Claire, post-course pilot interview, February 3, 2015).

In this paper, we explored the potential of community-based learning as a social space that produces power and in which participants confront, challenge, and re-negotiate identities. In the process, we learn about the Other who might in fact be ourselves, and, sometimes taking a leap forward, we "let that breath go and allow ourselves to go far."

\section{Notes}

1. We take our definition of bilingualism and bilingual from Flores and Schissel (2014), and Hornberger (2003), as a spectrum of language competence. In this article, bilingual is an umbrella term that includes English Learner, emerging bilingual, and multilingual.

2. Articulated by Dr. Martha Kanter, U.S. Under Secretary of Education in 2012, on the occasion of the meeting of the G8, May, 2012.

3. Protocol \# E15-165.

4. Pseudonyms are used throughout. 


\section{References}

American Council on the Teaching of Foreign Languages (2014). Global competence position statement. Retrieved from http://www.actfl.org/news/ position-statements/global-competence-position-statementon 03/30/2016

Angelova, M. (2001). Learning through service: Service-learning projects in a TESOL program. In S. Mullett (Ed.), Service-learning research K-16: Innovation and change in American education (pp. 15-20). Scotts Valley, CA: National Service Learning Clearinghouse.

Auerbach, E. R. (1993). Reexamining English-only in the ESL classroom. TESOL Quarterly, 27(1), 1-18.

Avineri, N. (2015). Nested interculturality, multiple knowledges, and situated identities through service-learning in language education. In J. Perren \& A. Wurr (Eds.), Learning the language of global citizenship: Strengthening service-learning in TESOL (pp. 197-223). Champaign, IL: Common Ground Publishing.

Bakhtin, M. (1935/1981). The dialogic imagination: Four essays by M.M. Bakhtin. M. Holquist (Ed.). Austin, TX: University of Texas Press.

Bale, J. (2011). Tongue-tied: Imperialism and second language education in the United States. Critical Education, 2(8), 1-25.

Barkhuizen, G. (2016). Narrative approaches to exploring language, identity and power in language teacher education. RELC Journal, 47(1), 25-42.

Belz, J. (2003). Linguistic perspectives on the development of intercultural competence in telecollaboration. Language Learning \& Technology, 7(2), 68-99.

Blommaert, J., \& Backus, A. (2013). Superdiverse repertoires and the individual. In I. de Saint-Georges \& J.-J. Weber (Eds.), Multilingualism and multimodality: Current challenges for educational studies (pp. 11-32). Rotterdam, United Kingdom: Sense Publishers.

Boyle-Baise, M., \& Kilbane, J. (2000). What really happens? A look inside servicelearning for multicultural teacher education. Michigan Journal of Community Service Learning, 7(1), 54-64.

Bremer, K., Roberts, C., Vasseur, M. -T, Simonot, M., \& Broeder, P. (1996). Achieving understanding: Discourse in intercultural encounters. London, United Kingdom: Longman.

Byram, M. (1997). Teaching and assessing intercultural communicative competence. Clevedon, United Kingdom: Multilingual Matters.

Byram, M. (2008). From foreign language education to education for intercultural citizenship: Essays and reflections. Clevedon, United Kingdom: Multilingual Matters. 
Byrd, D. R., Hlas, A. C., Watzke, J., \& Montes Valencia, M. F. (2011). An examination of culture knowledge: A study of 12 teachers' and teacher educators' beliefs and practices. Foreign Language Annals, 44(1), 4-39.

Curtis, J. H., \& Curran, M.E. (2015). "Who's helping?": Conceptualizing citizenship in a community-based English language program. In J. Perren \& A. Wurr (Eds.), Learning the language of global citizenship: Strengthening servicelearning in TESOL (pp. 468-502). Champaign, IL: Common Ground Publishing.

Darling-Hammond, L. (2009). Teacher education and the American future. Charles W. Hunt Lecture. Paper presented at the annual meeting of the American Association of Colleges for Teacher Education, Chicago, IL.

Davies, B., \& Harré, R. (1990). Positioning: The discursive production of selves. Journal for the Theory of Social Behavior, 20(1), 43-63.

DeFina, A., \& Georgakopoulou, A. (2012). Analyzing narrative. Cambridge, United Kingdom: Cambridge University Press.

De Leon, N. (2014). Developing intercultural competence by participating in intensive intercultural service-learning. Michigan Journal of Community Service Learning, 21(1), 17-30.

Dervin, F., \& Machart, R. (2015). Cultural essentialism in intercultural relations. London, United Kingdom: Palgrave Macmillan.

Dooley, K. (2009). Intercultural conversation: Building understanding together. Journal of Adolescent and Adult Literacy, 52(6), 497-506.

Dooly, M. A. (2011). Crossing the intercultural borders into 3rd space culture(s): Implications for teacher education in the twenty-first century. Language and Intercultural Communication, 11(4), 319-337.

Feistritzer, C. E. (2011). Profile of teachers in the U.S. National Center for Education Information. Retrieved from http://www.edweek.org/media/ pot2011final-blog.pdf

Flores, N., \& Schissel, J. (2014). Dynamic bilingualism as the norm: Envisioning a heteroglossic approach to standards-based reform. TESOL Quarterly, 48(3), 454-479.

Flower, L. (2002). Intercultural inquiry and the transformation of service. College English, 65(2), 181-201.

Gándara, P., \& Hopkins, M. (2010). Forbidden language: English learners and restrictive language policies. New York, NY: Teachers College Press.

Gorski, P.C. (2008). Good intentions are not enough: A decolonizing intercultural education. Intercultural Education, 19(6), 515-25.

Haddix, M. (2015). Preparing community-engaged teachers. Theory Into Practice, 54(1), 63-70. 
Hornberger, N. (2003). Continua of biliteracy: An ecological framework for educational policy, research, and practice in multilingual settings. Bristol, United Kingdom: Multilingual Matters.

Hua, V. (2014). Exploring intercultural communication: Language in action. London, United Kingdom: Routledge.

Hutchinson, M. C. (2011). Impacting pre-service teachers' sociocultural awareness, content knowledge and understanding of teaching ELLs through service-learning. Journal of Research on Service-learning in Teacher Education, 1(2), 31-35.

Kanter, M. (2012). Broadening the spirit of respect and cooperation for the global public good. Presentation to International Education Summit on the occasion of the meeting of the G-8, convened May 3, 2012, Washington, DC, USA.

Kearney, E. (2015). Intercultural learning in modern language education. Clevedon, United Kingdom: Multilingual Matters.

Kinginger, C. (2013). Identity and language learning in study abroad. Foreign Language Annals, 46, 339-358.

Kozma, C. (2015). Intercultural inquiry as a framework for service-learning course design. Journal for Civic Commitment, 23, 1-19.

Kramsch, C. (1998). Language and Culture. Oxford, United Kingdom: Oxford University Press.

Kramsch, C. (2014). Language and culture. AlLA Review, 27, 30-55.

Kramsch, C., \& Nolden, T. (1994). Redefining literacy in a foreign language. Die Unterrichtspraxis, 27(1), 28-35.

Kramsch, C., \& Whiteside, A. (2008). Language ecology in multilingual settings: Towards a theory of symbolic competence. Applied Linguistics, 29(4), 645671.

Ladson-Billings, G. (2006). It's not the culture of poverty, it's the poverty of culture: The problem with teacher education. Anthropology and Education Quarterly, 37(2), 104-109.

Leh, J. M., Grau, M., \& Guiseppe, J. (2015). Navigating the development of preservice teachers' intercultural competence and understanding of diversity: The benefits of facilitating online intercultural exchange. Journal for Multicultural Education, 9(2), 98-110.

Levine, G. (2013). The case for a multilingual approach to language classroom communication. Language and Linguistics Compass. 7(8), 423-436.

LoBianco, J. (2014). Domesticating the foreign: Globalization's effects on the place/s of languages. Modern Language Journal, 98(1), 312-325.

Malewski, E., Sharma, S., \& Phillion, J. (2012). How international field experiences promote cross-cultural awareness in preservice teachers through 
experiential learning: Findings from a six-year collective case study. Teachers College Record, 114(8), 1-44.

Martín-Rojo, L. (2013). From language practices to social processes: The understanding of linguistic "respect" in contact zones. In I. de Saint-Georges \& J-J. Weber (Eds.), Multilingualism and multimodality: Current challenges for educational studies (pp. 33-58). Rotterdam, United Kingdom: Sense Publishers.

Mencken, K. (2008). English learners left behind: Standardized testing as language policy. Clevedon, United Kingdom: Multilingual Matters.

Moll, L.C., Amanti, C., Neff, D., \& González, N. (1992). Funds of knowledge for teaching: Using a qualitative approach to connect homes and classrooms. Theory Into Practice, 31(2), 132-141.

Norton, B. (2013). Identity and language learning: Extending the conversation. Toronto, Canada: Multilingual Matters.

Overfield, D. (2007). Conceptualizing service-learning as second language acquisition space: Directions for research. In A. Wurr \& J. Hellebrandt (Eds.), Learning the language of global citizenship (pp. 58-81). Bolton, MA: Anker.

Palmer, D. K., \& Menard- Warwick, J. (2012). Short-term study abroad for Texas pre-service teachers: On the road from empathy to critical awareness. Multicultural Education, 19(3), 17-26.

Palpacuer, C. (2010). Educating the gaze or the art of perspective. In F. Dervin and B. Francchiolla (Eds.) Anthropologies, Interculturalité, et Enseignement-Apprentissages des Langues [Anthropology, Interculturality, and language learning-teaching] (pp. 118-143). Bern, Switzerland: Peter Lang.

Perren, J., \& Wurr, A. (Eds.). (2015). Learning the language of global citizenship: Strengthening service-learning in TESOL. Champaign, IL: Common Ground Publishing.

Pennycook, A. (2007). Global Englishes and transcultural flows. London, United Kingdom: Routledge.

Phipps, A., \& Levine, G. (2012). What is language pedagogy for? In G. Levine \& A. Phipps (Eds.), Critical and intercultural theory and language pedagogy (pp. 1-14). Boston, MA: Heinle/Cengage.

Porto, M. (2015). Ecological and intercultural citizenship in the primary English as a Foreign Language (EFL) classroom: An online project in Argentina. Cambridge Journal of Education. doi: 10.1080/0305764X.2015.1064094

Porto, M., \& Byram, M. (2015). A curriculum for action in the community and intercultural citizenship in higher education. Language, Culture and Curriculum, 28(3), 226-242.

Ramanathan, V. (2013). Language policies and (dis)citizenship: Rights, access, pedagogies. Bristol, United Kingdom: Multilingual Matters. 
Rampton, B., \& Charalambous, C. (2016). Breaking classroom silences: A view from linguistic ethnography. Language and Intercultural Communication, 16(1), 4-21.

Sadler, M. (2014). Co-constructing intercultural views and identities in a teaching methods class. Proceedings of the Intercultural Competence Conference. Tucson, AZ: CERCLL.

Smolcic, E., \& Katunich, J. (2017). Teachers crossing borders: A review of the research into cultural immersion field experiences for teachers. Teaching and Teacher Education, 62, 47-59.

Scarino, A. (2014). Language as reciprocal, interpretive meaning-making: A view from collaborative research into the professional learning of teachers of languages. Modern Language Journal, 98(1), 386-401.

U.S. Census Bureau (2014). Statistics for [CITY NAME]. http://www. census.gov/quickfacts/table/

Ware, P. D. (2016). Intercultural competence inside digital contact zones: Spaces of reification, negotiation and suspense. Plenary Address at the Fifth International Conference on the Development and Assessment of Intercultural Competence. Tucson, AZ.

Ware, P.D., \& Kramsch, C. (2005). Toward an intercultural stance: Teaching German and English through telecollaboration. The Modern Language Journal, 89(2), 190-205.

Wenger, E. (1998). Communities of practice: Learning, meaning, and identity. Cambridge, United Kingdom: Cambridge University.

Wortham, S. (2001). Narratives in action: A strategy for research and analysis. New York, NY: Teachers College Press.

Wortham, S. (2004). From good student to outcast: The emergence of a classroom identity. Ethos, 32(2), 164-187.

Wurr, A. (2013). Engaged teaching and learning: Service-learning, civic literacy, and TESOL. TESOL Journal, 4(3), 397-401.

\section{Author Contact}

Christelle Palpacuer-Lee: christelle.palpacuer-lee@gse.rutgers.edu

Rutgers University, 10 Seminary Place, New Brunswick, NJ 08901

Jessie Hutchison Curtis: jessie.curtis@gse.rutgers.edu

Rutgers University, 10 Seminary Place, New Brunswick, NJ 08901 